UNITED STATES DEPARTMENT OF THE INTERIOR

Ray Lyman Wilbur, Secretary

GEOLOGICAL SURVEY

W. C. Mendenhall, Director

\title{
Bulletin 836
}

\section{MINERAL RESOURCES \\ OF ALASKA}

\section{REPORT ON PROGRESS OF INVESTIGATIONS IN}

\section{0}

BY

PHILIP S. SMITH AND OTHERS

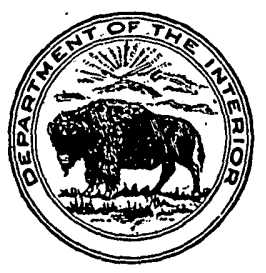

UNITED STATES

GOVERNMENT PRINTING OFFICE

WASHINGTON : 1933

For sale by the Superintendent of Documents, Washington, D. C. - - - - - Price. 75, cents. 


\section{CONTENTS}

Page

Mineral industry of Alaska in 1930, by P. S. Smith

Administrative report, by P. S. Smith

Notes on the geography and geology of Lituya Bay, by J. B. Mertie, jr

Surface water supply of southeastern Alaska, 1909-1930, by F. F.

Henshaw

The eastern portion of Mount McKinley National Park, by S. R. Capps_-

The Kantishna district, by F. H. Moffit

Mining development in the Tatlanika and Totatlanika:Basins, by

F. H. Moffit

The Tatonduk-Nation district, by J. B. Mertie, jr.

Index

Selected list of Geological Survey publications on Alaska

\section{ILLUSTRATIONS}

Plate 1. Map of southeastern Alaska showing location of gaging stations, precipitation stations, and water-power developments_-

2. $A$, Swan Lake and outlet, Revillagigedo Island; $B$, Salmon Creek Reservoir, near Juneau._._. 148

3. $A$, Dorothy Lake; $B$, Dorothy Creek, Lieuy and Bart Lakes _-_ 149

4. Geologic reconnaissance map of central Alaska__._._._._-_. 228

5. Map of lode claims in the vicinity of Fridas and Eureka Creeks_ 324

6. Assay map of Liberty Bell mine_._. 340

7. Geologic reconnaissance map of the Tatonduk-Nation district- 368

FiguRE 1. Trends of mineral production of Alaska, 1890-1930

2. Trend of value of gold production of Alaska, 1880-1930____- 11

3. Copper produced from Alaskan mines, 1900-1930, and fluctuations in the price of copper during that period__-_...-.-.- $\quad 60$

4. Map of Lituya and vicinity

5. Map of central portion of Baranof Island__________-_-_ 152

6. Index map showing location of the eastern portion of Mount McKinley National Park

7. Distribution of timber in eastern portion of Mount McKinley National Park

8. Sketch map of tunnel and shafts on the Red Top claim

9. Drift and crosscuts on the Litttle Annie claim

10. Sketch map of claims on Eva Creek

11. Index map showing location of Tatonduk-Nation district.-.-

12. Curves showing mean precipitation and mean temperature at Eagle

13. Appressed folding in slates of Tindir group on Waterfall Creek 